\title{
The Islamic State (IS) and the Sudanese "Mahdiyyah": A Comparative Analysis of Two Failed Apocalyptic Jihadist States
}

\author{
Dr. Anthony Celso* \\ Professor, Department of Security Studies and Criminal Justice at Angelo State University in San, Angelo \\ Texas, USA
}

*Corresponding Author: Dr. Anthony Celso, Professor, Department of Security Studies and Criminal Justice at Angelo State University in San, Angelo Texas, USA

\begin{abstract}
This essay's compares two millenarian jihadist state movements (the 21st century Islamic State and the 19th century Sudanese Mahdiyyah) and the security challenges they posed to the international order. It does so in three parts. First, it provides an overview of the apocalyptic component in Sunni Islam that guided these movements. Second, it assesses their leadership and ideology. Finally, it compares the defeat of the Mahdist state with the Islamic State's caliphate's collapse.
\end{abstract}

Keywords: Jihad, Prophecy, Apocalyptic, Sectarianism and Terror

\section{INTRODUCTION}

The Islamic State of Iraq (ISI) June 2014 formation of a transnational caliphate was an extraordinary development. Driven by a sectarian and apocalyptic ideology ISI's Iraqi-Syrian jihadist state presented significant regional and global security challenges. Badly damaged by Post 2006 US counter terror operations and a Sunni tribal uprising against ISI predecessor Al Qaeda in Iraq (AQI), the Islamic State of Iraq made a remarkable resurgence. After the 2011 US military withdraw, a Shia dominated government in Baghdad pursued polices repressing the Sunni minority. Its politicians were prosecuted for supporting terrorism, Sunni army officers were demoted, and Anbar based tribal militias were dismembered. ${ }^{1}$ Sunni protests against Baghdad's discriminatory policies were savagely crushed. ISI was able to recover as a protector of Sunni interests.

By 2013 Islamic State of Iraq (ISI) rebuilt its terror network by securing tribal alliances and replenished its ranks by attacking correction facilities liberating hundreds of jihadist prisoners. ${ }^{2}$ The Syrian civil war, moreover, accelerated ISI's transnational expansion. Supported by its Syrian operations, ISIS conquered the Sunni heartland in Central-Western Iraq. On June 29, 2014 ISI spokesman Abu Muhammad al-Adnani declared a caliphate called The Islamic State (IS). ${ }^{3}$ Adnani's decree was sanctified by IS' emir Abu Bakr al-Baghdadi's Mosul Grand Mosque July 2014 sermon that demanded the loyalty of world's Muslims and their emigration to the caliphate. ${ }^{4}$ By declaring a caliphate Baghdadi's (self-proclaimed as Caliph Ibrahim) IS sought regional hegemony. The Islamic State's caliphate had support from thirty terror networks including Egypt's Ansar al Jerusalem and Nigeria Boko Haram. One year after its formation the caliphate had amassed provinces (wilayats) in Algeria, Libya, Egypt, Yemen, Saudi Arabia, Nigeria, Khorasan (Afghanistan-Pakistan) and the

\footnotetext{
${ }^{1}$ Pollack, K, "The Fall and Rise and Fall of Iraq" July 30, 2013 access at http://www.brookings.edu/research /papers/2013/07/30-fall-rise-fall-iraq-pollack.pdf

${ }^{2}$ Lewis, J. “AQI's 'Soldiers of Harvest' Campaign” The Institute for the Study of War October 9, 2013 accessed at http://wwwundeerstandingwar.org/sites/default/files/BackgroundSoldiersHarvest.pdf

3“"The Return of the Khilafah" Dabiq 1 al-Hayat Media Center accessed at http://www.jihadology.net/ 2014/07/05/al\%e\%68\% sayat-media-center-presents-a-new-issue-of-the-islamic-state-magazine-dabiq1/ ;Roggio B., "ISIS announces formation of a Caliphate, rebrands as Islamic 'State"' June 29, 2014 The Long War Journal accessed at: http:/ www.thelongwarjournal.org/threatmatrix/archives/2014/06/isis_anounces_formation_of_a_ ca..php.

${ }^{4}$ Roggio, ibid
} 
Caucasus. ${ }^{5}$ By 2015 the Islamic State ruled over six million people subjecting them to terrible predations.

IS' creation of the caliphate, moreover, reverberated across the jihadist world. Al Qaeda's (AQ) leadership viewed Baghdadi's quest to for a Syrian-Iraqi transnational state as a bid to dominate the global jihadist movement. Reacting to Baghdadi's February 2014 creation of the Islamic State of Iraq and al-Sham (ISIS) that unified his Iraqi ISI and Jabhat al Nusra (JN) Syrian operations, AQ emir Ayman al-Zawahiri nullified the union demanding that Baghdadi cede authority over Syrian operations to JN emir Abu Muhammad al-Golani. Baghdadi sharply rebuked Zawahiri's commands. After Baghdadi's refusal relations between the two worsened and by January 2014 ISI and AQ affiliated JN fought each other in Syria. Thousands of jihadists died. One month later Zawahiri expelled ISIS from AQ's network. ${ }^{6}$

IS was the largest, best financed and armed jihadist state in history. As expressed in its media operations IS confidence derived from its apocalyptic ideology. The caliphate's internet channels posted beheadings, stoning, crucifixion, immolations and drowning of prisoners that shocked the world. The closest historical precedent we have to IS is the $19^{\text {th }}$ century Mahdist revolt and its creation of a jihadist state. From 1885-98 the Mahdiyyah challenged the Ottoman and British Empires. ${ }^{7}$ The $19^{\text {th }}$ century Mahdist revolutionary state has interesting parallels to IS' caliphate. It was also a dramatically different type of jihadi state where Sufism moderated its violent predations and expansionism.

Driven by an apocalyptic ideology the Mahdists wanted to build a caliphate to "liberate" Jerusalem and "occupy" Constantinople. ${ }^{8}$ Like its modern brethren the Mahdists fought a declining Western power. Khartoum's fall to Mahdist forces and their butchering of its British commander General "Chinese" Gordon in 1885 have their parallel in the 2014 collapse of the American armed and trained Iraqi army. Like the United States early efforts to "degrade" and "defeat" the Islamic State, imperial Britain initially waged a limited military campaign against the Mahdists by assisting local forces. After repeated defeats of Egyptian-Sudanese expeditionary forces by the Mahdiyyah's fanatical warriors and a failed decade long limited campaign to overturn the Mahdiyyah, Britain found the will to use its own ground troops against the Mahdiyyah. ${ }^{9}$ When the Mahdist state was vanquished, British technological superiority and massive firepower were decisive. The Mahdiyyah's demise foreshadowed the destruction of IS' jihadi state that by late 2017 saw its twin capitals of Mosul and Raqqa fall to internationally assisted local forces and its caliphate liquidated.

This essay's compares two millenarian jihadist state movements and the security challenges they posed to the international order. It does so in three parts. First, it provides an overview of the apocalyptic component in Sunni Islam that guided these movements. Second, it assesses their leadership and ideology. Finally, it compares the defeat of the Mahdist state with the Islamic State's caliphate's collapse.

\section{SUNNI APOCALYPTIC VISIONS}

Like Judaism and Christianity, Islam envisions a cataclysmic end to the world. While a day of final judgment is contained in the Qur'an, its suras (chapters) say nothing about the eschatological events that bring about the world's end. ${ }^{10}$ Visions of the Islamic apocalypse are, however, suggested by the

\footnotetext{
${ }^{5}$ McFate, JL. et al., "ISIS Military Operations Ramadan: a Forecast" The Institute for the Study of War June 7, 2015 accessed at http://www.understandingwar.org/sites/default/files/ISIS\%20COAs\%20.final.pdf

${ }^{6}$ Jocelyn, T. (2014). "Al Qaeda General Command Disowns Islamic State of Iraq and the Sham" Long War Journal Feb. 3, 2014 access at http://www.longwarjournal.org/archives/2014/02/al_qaedas_general_cp.php

${ }^{7}$ Fradin, MS. Jihad: the Mahdi Rebellion in the Sudan (Authors Choice Press: New York, 2003); Holt, PM., The Mahdist State in the Sudan $2^{\text {nd }}$ edition (Clarendon Press: Oxford, 1970); Byron Farwell, Prisoners of the Mahdi (W.W. Norton: New York, 1989); Butler, DA. The First Jihad: Khartoum, and the Dawn of Militant Islam Kindle Edition(Casemate: Drexel Hill, 2007)

${ }^{8}$ Holt, ibid, 112-116

${ }^{9}$ Farwell, B. Prisoners of the Mahdi (W.W. Norton: New York, 1989), 81-100

${ }^{10}$ Filiu, JP, Apocalypse In Islam (University of California Press: Berkley, 2011) No Qur'anic passages for the chain of events
} 
Prophet's words as recorded by his companions and followers. Hundreds of these hadith exist and some express millenarian visions of the "signs of the hour" and a "final battle". ${ }^{11}$

These hadith foretell a Muslim world weakened by intra-civilizational conflict [fitnah] and a final battle pitting Muslim armies against diabolical crusader forces. This final battle is, however, a consequence of a complex set of forces. Faced with internal religious decay, the Muslim world is redeemed by a "rightly guided leader" (the Mahdi) who purifies Islamic civilization by restoring Sharia law and defeating Western crusader forces. Within this eschatological tradition Jesus [Issa] descends from heaven to help the Mahdi defeat the anti-Christ's [Dajall] leading to global Islamic conquest and the creation of an earthly paradise. ${ }^{12}$

These "signs of the hour" foretell internal and external conflict where a resurgent victorious Islam conquers its co-religious and foreign enemies. One hadith speaks of a titanic battle in the Levant near the Syrian town of Dabiq where Muslim forces defeat the Romans. ${ }^{13}$ Named after this prophesied battle IS ex-English language magazine Dabiq predicted the caliphate's annihilation of the West and its Shia [rafidah] proxies. The leader of the Mahdist revolt Muhammad Ahmed "prophetic dreams" fueled his desire for imperial conquest. ${ }^{14}$

Under Islamic millenarian, the Mahdi is a pivotal figure in Islam's self-purification and refortification. ${ }^{15}$ His rise, however, is predicated upon the emergence of violent fault lines and intraconfessional antagonisms. Within this context, the Mahdist and Islamic State revolts were responses to the "internal rot" of Muslim society created by what they believed was the faith's "accretion" of foreign influences. Like IS leader Abu Bakr al-Baghdadi, Muhammad Ahmed wanted to purify Muslim society by eviscerating Ottoman apostasy and restoring Sharia. ${ }^{16}$

The 1881 Mahdist revolt borrowed from the Sufi mystic traditions of a "rightly guided" leader who corrects the world's injustices. ${ }^{17}$ Sudan's harsh conditions, draught, famine and brutal foreign domination may have fortified a spiritual movement hoping for a divinely anointed agent to relieve mass suffering. Mystical journeys, asceticism, dreams and clairvoyant visions are prominently featured in Sufi traditions. Sufi doctrine in the Sudan evolved out of the teachings of hundreds of religious orders [tariqa] dominated by sheiks who commanded cult like followings. ${ }^{18}$

Egypt's 1821 Sudanese conquests clashed with Sufi religious orders that refused to abide by the rulings of Cairo's religious scholars. Sufism evolved into a form of religious and political resistance to Turko-Egyptian and later British colonial administration. ${ }^{19}$ Harsh Egyptian taxation and British efforts to abolish the slave trade created Sudanese resentment and economic hardship. Spearheaded by the $18^{\text {th }}$ century Saudi Wahhabi movement, Salafi ideas reached Sudan by the late $19^{\text {th }}$ century. ${ }^{20}$ The Wahhabis believed that that Ottoman deviation from orthodox doctrines and practices had weakened the Islamic community's (ummah) moral fabric. The Mahdist revolt's integration of Wahhabi ideals and Sufi mysticism created an explosive mix of ideas.

Having spent decades as a popular ascetic preacher, Muhammad Ahmed's June 1881 Mahdi selfdeclaration sent off shockwaves across Sudan. ${ }^{21}$ Egyptian colonial administration efforts to force his capitulation were rebuffed. Emboldened by the Mahdi's resistance Ahmed's supporters massed into

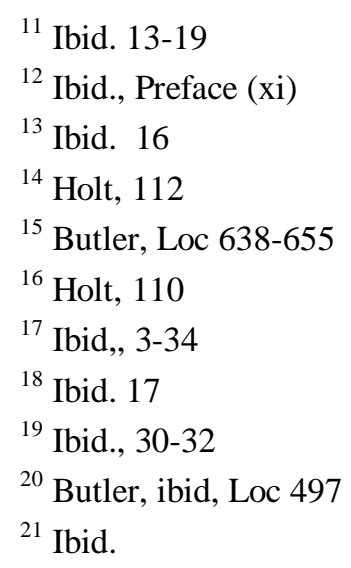


armed revolutionary movement. The Mahdi's primitive but fanatical army devastated four Egyptian military expeditions and his Ansars [partisans] threatened to invade Egypt. ${ }^{22}$

Among modern jihadist movements IS and the Mahdists are anomalies. Contemporary jihadism has mostly been devoid of apocalyptic orientations. Al Qaeda's ideological doctrine eschews millenarian themes. ${ }^{23}$ Beyond the Sudanese $19^{\text {th }}$ century Mahdiyyah and the Islamic State, only the 1979 Mecca Grand Mosque seizure by an apocalyptic cult led by Juhayan al-Otaybiis notable. Believing it divinely inspired Juhayan's cult declared one of its leaders the Mahdi hoping its mosque seizure would trigger the apocalypse. ${ }^{24}$ After a tense four week mosque siege, Saudi and French Special Forces put an end to the crisis. During the raid the self-appointed Mahdi and many of his followers were killed. Surviving cult members were subsequently tried and most were executed.

Thomas Hegghammer interpreted the event as an eccentric oddity attributable to peculiar group dynamics and personality disorders. ${ }^{25}$ What began as a quietest Salafi movement morphed into a selfdestructive cult. Despite Juhayan's failure there has been a revival in the popularity of Islamic apocalyptic ideas. Jean Pierre Filiu argues that political crises and the advent of a new century in the Muslim world historically have been linked to apocalyptic revivalism. ${ }^{26}$ The Iranian Revolution and the Afghan Jihad catalyzed Shi' ite and Sunni millenarian study and speculation. ${ }^{27}$ While many post 1979 apocalyptic theories erroneously interpret hadith and feature diabolic Judeo-centric conspiracy theories, they represent a deep Islamic millenarian undercurrent. Given the interest in Islamic eschatology, Filiu concludes that apocalyptic jihadist groups have enormous growth potential. ${ }^{28}$

Often considered a secondary driver of Islamic violence, jihadist ideology is beginning to be taken seriously by scholars. ${ }^{29}$ The growing academic focus on ideology as a prime catalyst for jihadist groups is being extended to the study of jihadism's millenarian dimensions. With the rise of ISIS apocalyptic ideology, scholarly analysis of Islamic eschatology has burgeoned. ${ }^{30}$

Brookings Institution scholar William McCant argues that IS' predecessor Islamic State of Iraq (ISI) viewed one of its leaders as the Mahdi and that its formation of a Sunni jihadist state in 2006 was designed to spark divine intercession. ${ }^{31}$ ISI's Post- Zarqawi leaders Abu Hamza-Muhajir and Abu Umar al-Baghdadi emphasized apocalyptic and sectarian orientations. Faced with targeted assassination by US Special Forces and an anti-Al Qaeda rebellion in Anbar Province the group's delusions may have been a psychological reaction to severe adversity. According to McCants, the ISI's decline and the killing of its key leaders in 2010 prompted a reformulation of its apocalyptic messaging.

Re-invigorated under Abu Bakr al-Baghdadi IS apocalyptic message emphasized the group's role in preparing for the Mahdi's emergence and its media organs prioritizes the caliphate as prophetic mechanism to purify the Muslim world and defeat crusader and Shi'ite apostate forces. This caliphate centric focus was officially proclaimed in July 4, 2014 by IS emir Baghdadi. His Mosul Grand

\footnotetext{
${ }^{22}$ Ibid, Loc 1,300

${ }^{23}$ Filiu, ibid, 186

${ }^{24}$ Hegghammer, T. and Stephen Lacroix, The Meccan Rebellion: the Story of Jubayan al-Utaybi Revisisted(Bristol: Amal Press, 2011)

${ }^{25}$ Ibid. (x), (xii)

${ }^{26}$ Filui, ibid, 9

${ }^{27}$ Ibid., 141-164

28 Ibid, 193

${ }^{29}$ Berman, P. Terror and Liberalism (W.W. Norton: New York, 2003);Karsh, E. Islamic Imperialism: A Short History (Yale University Press: New Haven, 2006); Bale, J. "Islamism and Totalitarianism" Totalitarian Movements and Political Religions 10:2 73-96

30 McCants, W. ISIS Apocalypse: the History, Strategy and Doomsday Vision of the Islamic State(Palgrave McMillian Trade: New York, 2015)

31 McCants, W., "ISIS and the Absent Mahdi: Studies in Cognitive Dissonance and Apocalyptic Jazz" presentation before Generation Caliphate: Apocalyptic Hopes, Millennial Dreams and Global Jihad Conference Center for Millennial Studies Boston University May 3-4, 2015 accessed at: http://www.bu.edu/history/newsevents/lecture-series-generation-caliphate-apocalyptic-hopes-millenial-dreams-global-jihad/
} 
Mosque sermon separates the world into competing belief systems pitting virtuous Muslims against devilish apostates. ${ }^{32}$

IS"s caliphate was viewed by its propagandists as a transitional stage to unite Muslims against diabolical forces. Its former English language magazine Dabiq emphasized Caliph Ibrahim religious authority and commitment to the "prophetic method". ${ }^{33}$ Unlike the Mahdists IS did not claim that Baghdadi is the righty guided one. His supposed lineage from the Prophet's tribe and his $\mathrm{PhD}$ in Islamic studies give Caliph Ibrahim religious legitimacy. ${ }^{34}$ Baghdadi like his ISI and AQI predecessors is viewed as part of a prophetic process that IS believes will culminate into an apocalyptic encounter with Shia and Crusader enemies. Based upon their reading of hadith IS' victory was seen by its partisans as preordained.

Muhammad Ahmed and his successor Khalifa Abdullah also employed prophetic imagery. There is little debate that the Mahdists were influenced by their belief in mystical forces. Khalifa Abdullah fateful decision to commit his 50,000 troops in an open field in broad day light against well-armed British-Egyptian forces at the disastrous battle of Omdurman was based on a dream that prophesied victory $^{35}$. Whether IS' core leaders apocalyptic beliefs are genuine is debatable. They have, however, made many of the Mahdiyyah's mistakes. Like IS' caliphate the Sudanese jihadist state brutality, fanaticism and conquests created an international uproar that threatened to overturn the regional balance of power. It remains an imperfect yet important historical precedent upon which to compare the Islamic State's rise and fall. The Mahdiyyah and the Islamic State have strong parallels. It is to this issue that we now turn.

\section{THE MAHDIST STATE AND IS: LEADERSHIP AND IDEOLOGY}

The Mahdist revolt was symptomatic of a crisis in the Muslim world. The Wahhabist movement that sought a return to traditional Islamic orthodoxy had profound ramifications across the world as early as the $18^{\text {th }}$ century. Its effects eventually reached the Sudan. ${ }^{36}$ The appeal of this fundamentalist world view accelerated as a reaction to Ottoman revisionism. The Empire's weakness by the $19^{\text {th }}$ century could no longer be denied. The Golden Age of Islam in the $16^{\text {th }}$ century had been steadily eclipsed by Western powers.

The Ottoman position in Egypt was one telltale sign of Empire's degeneration. As Ottoman proxies Egyptian rulers [Khedives) enjoyed broad autonomy. ${ }^{37}$ Largely self-governing the political relationship with the Turkish Sultan was symbolic. As in the Balkans and Central Asia Europeans became increasingly dominant in areas of historic Ottoman influence. Europeans controlled the bureaucratic administration of the Turko-Egyptian state and were prevalent in commerce. ${ }^{38}$ Egyptian armies were British armed and frequently led by retired British officers. France's 1869 completion of the Suez Canal invited British penetration of the region. Due to infrastructure development and an ambitious colonial policy the Egyptian state became financially overextended. Only British loans helped secure the fiscal solvency of the Khedives. British economic influence over Egyptian finances gave them enormous leverage to dictate policy.

Obligated to pay British banks Egyptian rule in the Sudan between1821-1885 was cruel and financially predatory. ${ }^{39}$ Impelled by British desires to end the lucrative slave trade, the Egyptians colonial authorities complied with London's orders. Between 1874-1879 Sudan's British Governor General George "Chinese" Gordon" zealously executed slavers and was brutally effective in the

\footnotetext{
32 “Dabiq 1, 10

${ }^{33}$ Ibid.

${ }^{34}$ Anderson, G. "Abu Bakr al-Baghdadi and the Theory and Practice of Jihad" Small War Journal August 1, 2014 accessed at http://wwwsmallwarjournal.com/author/gary-anderson

${ }^{35}$ Holt, ibid, 241-242

${ }^{36}$ Ibid. 19

${ }^{37}$ Ibid, 2-3

${ }^{38}$ Fradin, ibid.

${ }^{39}$ Ibid. 13-36
} 
performance of his duties. ${ }^{40}$ Financially crippled by oppressive Egyptian taxes and the slave trade abolition Sudan was ripe for rebellion. By 1881 political instability in Egypt forced the British to militarily intercede and end a nationalist military rebellion against Khedive Tewfik. ${ }^{41}$ Sensing an opportunity Muhammad's Ahmed's Mahdi self-declaration was an incendiary moment that cascaded into a jihadist revolt.

Born on an island off the river town of Dagola, Muhammad Ahmed rejected his family's boat making trade for an ascetic religious life. Studying under religious sheiks he was known for his piety, abstemiousness and religious commitment. Cast off by his mentor Sheik Muhammad Sherif'sfor his denunciation of singing and dancing at a circumcision feast Ahmed eventually formed his own religious order. ${ }^{42}$ Following his "visitation" by the Prophet the Mahdi at age 40 he would change Sudanese history and set in motion a movement that would bedevil the British Empire for over almost two decades.

Muhammad Ahmed's spiritual following was so profound his supporters never doubted his vision. His claimed descent from the Prophet's tribe and his physical appearance that featured a facial mole and a gap between his teach were congruent with hadith based prophecies. Like Baghdadi, the Mahdi made repeated calls for Muslims to make hijrah [immigration] to his movement. Hoping to forge an imperial army the Mahdi made jihad a sixth pillar of Islam. ${ }^{43}$

The Mahdi's religious authority made him an ideal populist leader. His vilification of Turkish apostasy (echoed in IS' English language magazine Dabiq and its successor Ruymiyyah fulminations against Shi'ite rafidah) aimed to cleanse foreign influence from the Sudan. ${ }^{44}$ His narrative of Sufi victimization echoes the Islamic States patronage of pious Sunnis persecuted by Shi'ite apostates. The economic suffering of the Sudanese and prevalence of Sufi mysticism combined to make Mahdism a revolutionary millenarian anti-colonial movement.

Sudan's Governor General Rauf Pasha viewed Muhammad's Ahmed's Mahdi declaration as an eccentricity and not a serious threat. His efforts to get the Sheik to recant his self-declaration were zealously rejected. As the Mahdi's popularity grew, the Governor General felt impelled to repress the movement. Early military expeditions were poorly led and despite their superior arms Egyptian troops were butchered by the Mahdi's fanatical supporters. After three failed attempts, the Egyptian Khedive raised a 10,000 man army led by British officers with advanced weapons to end the Mahdist jihadist revolt. ${ }^{45}$

Commanded by a retired British officer William Hicks the Egyptian force doggedly chased the Mahdist army. Denied adequate provisions, poorly trained and dehydrated Hick's forces easily fell in a Mahdist ambush. Some ten thousand Egyptian soldiers and all of their European officers died. Only a few hundred Ansar [partisans] perished. ${ }^{46}$ Having beaten four Turko-Egyptian military campaigns the Mahdi implemented his extremist vision. Like IS' former rule in Raqqa and Mosul, he imposed severe punishments for drinking, smoking, dancing, singing, gambling, thievery, swearing, and apostasy. ${ }^{47}$ Women were forcibly veiled and denied access if unaccompanied by a male companion to public places. Marital Infidelity was punished by stoning. Thieves had limbs amputated. Sufi religious orders that failed to swear loyalty were proscribed. Like today's IS militants, the Mahdi's Ansar swore total allegiance to their leader. War "booty" became the exclusive province of the state.

Driven by messianic fervor the Mahdi wanted to create a 19th century Sudanese version of the Prophet's community. Impelled by the same fanaticism, IS' rule in Raqqa was portrayed as its new

\footnotetext{
${ }^{40}$ Holt, 34-40

${ }^{41}$ Newsinger, J. Liberal Imperialism and the Occupation of Egypt in 1882" Institute for Race Relations 49:3 5475

${ }^{42}$ Holt, p. 45-49

${ }^{43}$ Butler, ibid. Loc 1057

${ }^{44}$ Holt, 110

${ }^{45}$ Ibid. 69-73

${ }^{46}$ Butler, Ibid. Loc 1039

${ }^{47}$ Holt, 130-131
} 
Medina. Dabiq's imaging of Syria's Raqqa's combined grisly stoning, crucifixion, beheadings, amputations and floggings with tranquil depictions of its charitable programs. ${ }^{48}$ The juxtaposition of harsh punishment and mercy remains was key IS propaganda motif. ${ }^{49}$ The Institute for the Study of War argues the IS developed governing capacity in Raqqa delivering basic services. ${ }^{50}$ Morality police patrolled the streets enforced mandatory prayers and banned alcohol, smoking, and music. Women were forced to wear the veil and be accompanied by a male companion.

Raqqa's model was imposed across the caliphate including Mosul's three million inhabitants. Viewed as shirk (polytheism) by IS militants, Mosul's Shi'ite mosques, tombs and shrines were destroyed, Christians were expelled and infidel Yazidi were enslaved or killed. ${ }^{51}$ Homosexuals were thrown off high buildings and IS' morality police strictly enforced Islamic norms with stern punishments. Primary, secondary and university education was reorganized to reflect Islamic values.

Like IS's summer 2014 Iraq blitzkrieg the Mahdi's military victories reverberated across the world. Hick's death and the Egyptian army calamitous defeat put pressure on Prime Minister William Gladstone's Administration to act decisively. The Mahdist revolt put Gladstone in a difficult position. The Prime Minister spent a career in the Liberal Party campaigning against the financial cost and military follies of the Empire and he wanted to limit overseas military adventures. ${ }^{52}$ Initially Gladstone thought the Sudan could be relinquished to Mahdist forces because it was not vital to British interests. Egypt, however, was another matter. The Khedive's debt to British banks and the strategic value of the Suez Canal were important core interests. ${ }^{53}$

Conservative Party parliamentary back-benchers protests over the slaughter of Hicks army forced the governments' hand. Ambivalent about intervention but conscious of the importance of political symbolism, Gladstone chose an English national hero George "Chinese" Gordon to assess the Sudan's security situation. The Administration tasked Gordon to secure the evacuation of European nationals from Khartoum. ${ }^{54}$ Gordon, however, zealously approached his job and he expanded the mission hoping a secure a British commitment to defend the city.

Defending Khartoum's 34,000 inhabitants with a force of only 8,000 Egyptian and Sudanese soldiers from the Mahdi's army was no easy task. ${ }^{55}$ The city's location on the river, however, allowed steamships to deliver needed supplies. Gordon, moreover, made some military incursions outside the city to acquire food. By March 1884 the Mahdi's army had laid siege dramatizing Gordon's precarious position. During Gordon's 317 day resistance against jihadist forces his exploits were reported by the British press and the Conservatives pleaded with Gladstone to send a military expedition to save the city. ${ }^{56}$ Doggedly determined to avoid yet another misguided military adventure Gladstone resisted until public pressure forced him to send a relief force. The decision, however, came too late. General Hook's army moved slowly across the Sudanese desert and arrived two days after the city fall. ${ }^{57}$ Over 30,000 people were killed by the Mahdi's enraged Ansar warriors. Those

\footnotetext{
${ }^{48}$ Caris, C and Samuel Reynolds," ISIS Governance in Syria" Middle East Security Report 22 July 2014 The Institute for the Study of War accessed at http://www.underderstandingwar.org/sites/default/files/ISIS_ Governance.pdf

49 Gambhir, HK, "Dabiq: The Strategic Messaging of the Islamic State" Backgrounder August 15, 2014 The Institute for the Study of War accessed at http://understandingwar.org/sites/defalt/files/Dabiq\%20 Backgounde_Harleen \%20Final.pdf.

${ }^{50}$ Ibid

51 "Smashing the Borders of the Tawaghit" Islamic State Report 4Alhayat Media Center accessed at http://jhadology.net/.../al-hayat-media-center-presents-a-new-issue-of-the-islamic-state-of-iraq-and-al-shammagazine-islamic-state-report-4/ 3

${ }^{52}$ Newsinger, ibid

${ }^{53}$ Ibid

${ }^{54}$ Butler, ibid, Loc 1334

${ }^{55}$ Ibid, Loc 1837-2203

${ }^{56}$ Holt 95-103,

${ }^{57}$ ibid, 103-104
} 
lucky to survive the massacre were sold off into slavery. Gordon fell fighting on the Governor's palace steps run through with an Ansar spear and beheaded.

Emboldened by his "prophetic victories" the Mahdi's ambitions had few limits. His visions of conquering Constantinople, Jerusalem, Mecca and Medina were eerily reminiscent of Baghdadi's aspirations to restore the territory of past caliphates. Like IS' leaders the Mahdists demanded the total capitulation and repentance of enemies. Hoping to forge a Pan-Islamic movement the Mahdi sought to secure the bay'ah of prominent sheiks in Morocco, Libya and Nigeria. ${ }^{58}$

Despite the outcry associated with Gordon's beheading, Gladstone never took action against the Mahdi's forces in the Sudan. Four months after Khartoum's fall, the Mahdi became ill and died of malaria. Selected to be his successor Khalifa Abdullah Ibn Sayid Muhammad consciously exploited the Mahdi's memory. ${ }^{59}$ For 13 years Abdullah remained faithful to the Mahdi's fanatical vision. Abdullah rose to prominence as a religious student under the future Mahdi who like the Prophet picked four successors (khalifas). Like the Islamic State the Mahdist regime delegated autonomy to regional commanders. Before its demise as a state entity IS bifurcated Iraq and Syria into separate military commands with each nation de-compartmentalized into 10 provinces (wilayats) governed by local emirs. ${ }^{60}$ The Mahdi's demarcated his three khalifas by the color of their army's flag. ${ }^{61}$ Each khalifa exercised rule over their territories provided they were faithful to the Mahdi and their policies were consistent with his religious aims. Conscious of his predecessor "divine authority", Abdullah intensified the religious foundation of his state consecrating his eschatological role as the Mahdi's protector. Entombed in Khartoum the Mahdi's burial shite became a Sufi shrine.

IS similarly sees Abu Bakr al-Baghdadi's as part of a prophetic trajectory began by Abu Musab alZarqawi to fortify the ummah's capacity to defeat crusader forces. The Jordanian's mythic status is a predominant eschatological motif in IS" media operations. ${ }^{62}$ Dabiq began each edition with Zarqawi's quotation that his campaign in Iraq will inexorably lead to an apocalyptic battle. Islamic State publications interspersed Muhammad's life with the exploits of AQI and ISI leaders. Muhammad's hijrah (emigration) to Medina, his establishment of a devout community, his defeat of the pagans, his crushing of the "traitorous" Jews and his conquest of Mecca are juxtaposed with AQI's ideological, leadership and organizational trajectory. ${ }^{63}$ By linking Zarqawi with the Prophet, IS legitimated its effort to direct the global jihadist struggle and audaciously demanded bay'ah [loyalty] from all Muslims. Groups like Al Qaeda and Jabhat al Nusra that refuse to swear bay'ah to Baghdadi are considered apostates to be fought.

Emulating the Prophet Zarqawi made his hijrah from Jordan to Afghanistan to Iraq, fought against polytheists (the Shia) and infidels (U.S. forces) and the Jordanian wanted to recreate a modern version of the Prophet's state in Iraq's Anbar Province. Dabiq presented AQI leaders including Abu Bakr alBaghdadi as part of divine path of Islamic renewal, purification and conquest. ${ }^{64}$

Islamic State publications criticize Shi' ite and Kurdish apostasy and celebrate their slaughter. ${ }^{65}$ They depict a Muslim world plagued by shirk [polytheism] with pious Sunnis repressed by Shi'ite and Alawite tawaghit [despots] and their Zionist-Crusader masters. Based on Qur'anic verses and hadith Dabiq's first issue The Return of the Khilafah saw the Islamic State as Allah's prophesied vanguard to rejuvenate Islam by restoring tawid [unity], purging it of shirk [polytheism] and fortifying the true

\footnotetext{
${ }^{58}$ Holt, PM, "The Sudanese Mahdia and the Outside World" Bulletin of the School of Oriental and African Studies 21:1 276-296

${ }^{59}$ Holt, ibid, The Mahdist State in the Sudan, 122-125

${ }^{60}$ Lister, C, "Profiling the Islamic State" Brookings Doha Center Analysis Paper No. 13 November 14, 2014 accessed at http://www.brookings.org/research/files/reports/2014/11/profiling\%20islamic\%20state\%lister/inweb-lister.pdf

${ }^{61}$ Holt, Ibid. 119-122

62 Celso, A. “Zarqawi's Legacy: Al Qaeda's ISIS Renegade” Mediterranean Quarterly 26:2 DOI $10,2015 / 10474552-2914495$

63 "From Hijrah to Khalafah" in Dabiq 1 The Return of the Khalifah 34-40

${ }^{64}$ Ibid

${ }^{65}$ Islamic State Report 4, ibid.,
} 
ummah [community] by integrating political and religious authority under Caliph Ibrahim. ${ }^{66}$ Report on the Islamic State 4 venerated the slaughter of 1,700 Shi' ite army prisoners after Mosul's June 2014 fall. ${ }^{67} \mathrm{IS}$ ' militants proudly stand by mass graves in the edition's many horrific photos. Western hostages, Syrian soldiers and Christian Copts have been victims of grisly beheading internet posted videos.

Syria remains a fulcrum point for two rival Islamic millenarian movements. ${ }^{68}$ IS' brutal sectarian cleansing of Shi'ite and Alawite communities have galvanized Shi'ite Mahdist apocalyptic undercurrents. Under the Shi' ite Twelver tradition Muhammad's $12^{\text {th }}$ successor lay in suspended animation and he will be released by Allah during a period of existential Islamic crisis. ${ }^{69}$ Given the Syrian civil war's sectarian carnage many Iraqi, Afghan, Pakistani and Syrian Shi'ite militias see it a prophetic sign of the Mahdi's reemergence. Across Syria and Iraq Shi'ite militias fight Islamic State militants in an eschatological struggle to purify the world of diabolical forces.

\section{THE ISLAMic STATE AND MAHDist WORLD VieWS: RELigious PURIFICATION AND IMPERIAL EXPANSION}

The IS and the Mahdists are part of a Sunni Salafist-Jihadist movement committed to restore Islamic predominance after a period of jahiliyyah induced decline. Salafists argue that Muslim revisionist rulers wrongfully incorporated European practices in law, art, science, philosophy, warfare and governance in their societies. ${ }^{70}$ Assimilation of non-Islamic values expanded under the Ottoman Turks and then accelerated calamitously during colonialism and independence. The spread of Western secularism according to the Salafi worldview shattered the ummah's foundations by separating religious from political authority. IS' Dabiq argued this heretical deviation substituted divine practices (Sharia based rule) for the imperfection of manmade institutions. ${ }^{71}$ Islamic society, it contended, has been betrayed by a revisionist clergy (ulama) unwilling to defend traditional values and who are acquiescent to Westernized political elites. ${ }^{72}$

IS' interpretation of jahiliyyah references medieval scholars. Ibn Taymiyyah, for example, argued the Mongol rule after the Abbasid caliphate's collapse was harmful to Islamic society for Mongol practices were antithetical to the religion's original principles. ${ }^{73}$ Taymiyyah reasoned that Mongol conversion to Islam did not make them true Muslims for their rule was not Qur'an based. Given this violation of the divine path, Taymiyyah urged rebellion to restore Allah's true intent and reinvigorate the caliphate.

Islamic State views these alien influences as undermining the divine stitching of Muslim order. Dabiq's tale the Millah [path] of Ibrahim sees Islam's historical degeneration as legitimating secular

\footnotetext{
${ }^{66}$ Dabiq 1. ibid

${ }^{67}$ Islamic State Report 4, ibid

${ }^{68}$ Zelin, A. and Philip Smyth (2014), "The Vocabulary of Sectarianism" January 29, 2014The Washington Institute for Near Eastern Policy accessed at http://washingtoninstitute.org/policy-analysis/view/the-vocabularyof-sectarianism

${ }^{69}$ Filiu, ibid. 24-29

${ }^{70}$ Calvert, J. Sayyid Qub and the Roots of Radical Islam (New York :Columbia University Press, 2010) pages in jahiliyyah

${ }^{71}$ Ryan, MSW, "Dabiq: What the Islamic State's New Magazine Tells Us about Their Strategic Direction. Recruitment Patterns and Guerilla Doctrine", Jamestown Terrorism Monitor 0: (2014) accessed at http://www. jamestown.org/tm

72 "The Extinction of the Grey Zone" in Dabiq 7: From Hypocrisy to Apostasyaccessed athttp://www. clarionproject.org/news/Islamic-State-ISIS-Isil-propaganda-magazine-dabiq 54-58. This is a clear effort to appeal to all Muslims that there can no longer be a third choice between the West and the Islamic State and that IS will be successful in uniting the umma to destroy the crusader order.

${ }^{73}$ Wiktorowicz, Q. “A Genealogy of Radical Islam” Studies in Conflict \& Terrorism 28 (2005): 75-97 doi: 10.1080/10567100590905057; "The Extinction of the Grey Zone" Dabiq 7, ibid. The magazine cites a passage of Ibn Taymiyya about the martial and absolutist properties of Islam to debunk "revisionist" arguments that Islam is a pacifist religion. $22-23$
} 
tyrannical rulers. ${ }^{74}$ IS believes Muslim society has reverted back to a pre-Islamic state of ignorance or jahiliyyah. This progressive erosion of Qur'anic values, accordingly, led to the loss of Ottoman dynamism, the caliphate's 1919 collapse and colonial humiliation. Only by purging these alien elements can the divine stitching of Muslim order be restored and the ummah's military capacity fortified.

The Mahdist narrative similarly emphasized Ottoman moral corruption and jahiliyyah impelled Islamic regression. The term Turk became a Mahdist euphemism for un-Islamic and by 1881 Ottoman Egypt had become so intertwined with British military power and commerce, it was seen as an extension of Imperial Britain. ${ }^{75}$ Like IS, the Mahdists bi-furcated the world into a house of belief (Dar al Islam) and the world of the disbelieving kuffar [Dar al Harb] outsider. The Mahdi's quest to expunge apostate Turkish rule from the Sudan resulted in Sharia law imposition and the restitution of slavery. Mimicking Muhammad rule in Medina, the Mahdists hoped that such measures would lead to further military victories.

Restoring slavery was also an IS theme. Dabiq defends Yazidi [a polytheistic sect] enslavement as consistent with Mohammad's early rule and slavery's restitution is represented as a prophetic sign. ${ }^{76}$ When ISIS conquered northern Iraq, thousands of Yazidi girls and women were sold into sexual slavery and entire communities were butchered when they refused to covert. Since the Yazidi creed emphasizes a fallen angel from heaven (equated with Satan by IS ideologues) as humanity's protector, IS views the Yazidi as "devil worshipers" to be enslaved or killed.

The caliphate's implementation of Sharia law featured many punishments that the Mahdists instituted over 120 years ago. The Mahdiyyah was especially brutal punishing such libertine enjoyments as smoking (100 lashes) and drinking (80 lashes) and they prohibited music, dancing, feasts, jewelry and abusive language. ${ }^{77}$ In adultery and fornication cases the Mahdiyyah beheaded men and stoned women. The IS zealously enforced stoning, beheadings, has cast off homosexuals from high buildings and its Sharia courts have executed "witches". The Islamic State executions featured burnings, drowning, firing squads and slitting of throats. Its internet posted immolation of Jordanian air force pilot was justified by referencing Muhammad's successor Abu Bakr use of fire against his enemies. ${ }^{78}$

The Mahdists sexual puritanism and misogyny also led them to enforce the veil and restrict women's movements. ${ }^{79}$ They prohibited unaccompanied women from entering public places and markets. Failure to adhere to these restrictions resulted in severe punishment. IS' justified its imposition of the veil as a means to restore women's honor and consecrate the rightful place as homemakers, child bearers and wives. IS media organs railed against Western sexual immorality, its denigration of marriage and its corruption of women ${ }^{80}$ The Islamic State's female brigade in Raqqa monitored women's public movements and IS female internet operators lured women to come to the caliphate and marry IS fighters. Emigration of British girls and entire families to Syria, alarmed London that belatedly cut the flow of its nationals to Baghdadi's then caliphate.

The Mahdists were a millenarian anti-colonial movement hoping to overturn a Western dominated regional order. Similarly IS's challenges Western hegemony. A IS documentary "The End of SykesPicot" announces that its caliphate has ended colonial era borders. ${ }^{81}$ The video brazenly abrogates the 1916 accord that divided the Ottoman Empire's Mideast territorial holdings between the French and the British colonizers.

\footnotetext{
74 "Imamah is from the Millah [Path] of Ibrahim" p 20-21 The Retrun of the Khalifah Dabiq 1, ibid.

${ }^{75}$ Holt, The Mahdist State and Society, ibid, 110

76 "The Revival of Slavery: Before the Hour" The Failed Crusade Dabiq 4http://www.clarionproject.org/news/ Islamic-State-ISIS-Isil-propaganda-magazine-dabiq414-18

${ }^{77}$ Holt, ibid. 130-131

78 "The Extinction of the Grey Zone" in Dabiq 7: From Hypocrisy to Apostasyaccessed athttp://www. clarionproject.org/news/Islamic-State-ISIS-Isil-propaganda-magazine-dabiq. 7

${ }^{79}$ Holt, ibid, 130

80 "The Extinction of the Grey Zone" in Dabiq 7: From Hypocrisy to Apostasy, ibid

${ }^{81} \mathrm{http}$ ///www.shariaunveiled.wordpress.com/2014/07/02/isis-end-of-sykes-picotvideo/commentpage.1/
} 
The Mahdi petitioned emirs and sheiks across the Muslim world to broaden his colonial resistance project. The Ottomans feared that the Mahdi's Sudanese revolution would spread and the Empire's troop presence rose appreciably in Medina and Mecca to avert similar rebellions. Unlike Abu Bakr alBaghdadi's July $4^{\text {th }}, 2014$ Mosul sermon for Muslims to emigrate to the newly formed caliphate, outside of Sudan few Muslims made hijrah to the Mahdiyyah. ${ }^{82}$ The Mahdiyyah's imperial incursions into apostate Egypt and Christian Abyssinia were, moreover, beaten back by opposing forces. Lacking sophisticated global media technology it failed to create a mass global jihadi movement. This is not the case regarding IS whose sophisticated media operations that has incubated the emigration of foreign fighters to its caliphate and encouraged its supporters living in the West to commit terrorist acts.

\section{MAHDIST SUFISM, IS SECTARIANISM AND GLOBALIZATION}

Despite their Salafi-Jihadist world view the Mahdiyyah and the Islamic State dramatically vary in many respects. The Mahdist doctrinal evolution from Sufism is a critical divergence and the $19^{\text {th }}$ century context they operated created a very different ideological and imperial trajectory. The Mahdists religious project was devoid of IS' sectarian brutality. There is little evidence that the Mahdists eviscerated shrines devoted to Muslim saints and its rule is absent of any desecration of Churches or destruction of pre-Islamic icons. When the Mahdi took Christian prisoners, a premium was put on their conversion and all but the most recalcitrant were well treated. ${ }^{83}$ One prisoner (Robert Satloff) even became an advisor to Khalifa Abdullah. Sufism acted as a moderating force.

Sufism in the Sudan was an ascetic spiritual quest led by revered Sheiks and diverse religious orders. Many of these sheiks were venerated and their capacity to innovate and interpret scripture led to a very decentralized and personalized belief system. Given its reverence for shrines devoted to past religious tutors, Sunni Sufi Islam shares much with the Shia branch of Islam. Muhammad Ahmed evolved from this tradition and while he demanded the loyalty of the Sufi orders little actions was taken to destroy them. His movement was not based on a rigid set of beliefs, but on charisma and divine leadership. ${ }^{84}$ After the Mahdi's death, the Mahdiyyah lost much of its revolutionary dynamism limiting its extremism and expansionism. Cultural and religious mores, moreover, may have blunted Mahdist Wahhabi tendencies. Consistent with its Sufi origins, the Madhiyyah revered its fallen leader whose tomb was considered a sacred shrine. The Mahdi's successor Abdullah furthermore lacked charisma and his capacity to inspire religious fervor among his adherents was limited.

The Islamic State contrastingly represented a more austere vision of Islam contemptuous of religious minorities and icons. The Islamic State's destruction of Shi'ite, Yazidi, Christian and Alawite communities, its desecration of ornate mosques and burial sites and its obliteration of pre-Islamic architectural ruins reflect an unrestrained Wahhabi- Salafi literalism. Despite being People of the Book, dozens of Christians have been beheaded by enraged IS militants, who from Libya's shores, swear that IS will conquer Rome. None of this behavior has a precedent during the Mahdiyyah. ${ }^{85}$

The international context IS operates in diverges from $19^{\text {th }}$ century Mahdist Sudan. Globalization's communication network and the rapidity of travel have allowed IS to project its influence and attract foreign fighters. Richard Barrett's for example argues that half of the 30,000 fighters that have traveled to Syria have entered IS ranks. ${ }^{86}$ Until 2017 its jihadist state stretched across parts of Iraq and Syria and its caliphate comprised wilayats/provinces in ten countries, IS' caliphate remains a global

\footnotetext{
${ }^{82}$ Holt, "The Sudanese Mahdia and the Outside World", ibid

${ }^{83}$ Farwell, ibid.

${ }^{84}$ Dekmejian, RH. and Margaret J. Wyszomorski, "Charismatic Leadership in Islam: the Mahdi of the Sudan" Comparative Studies in Society and History 14:2 193-214

85 Joscelyn, T. "21 Egyptian Christians beheaded in a ISIS Video" The Long War Journal February 15, 2015 accessed at: http://www.longwarjournal.org/archives/2015/02/15egyptian-christians.php
}

86 Barrett, R. The Islamic State November 2014 The Soufan Group accessed at: http/www.thesoufangroup.com/category/research/the-islamic-state/. Barrett calculates some 20,000 foreign fighters have gone to Syria half of whom have joined The Islamic State or Al Nusra 
entity. By some estimates IS had over fifty thousand fighters. ${ }^{87}$ Many of these now have died after three years of brutal warfare. Dabiq's savvy Madison Avenue style magazine was complemented by the Hollywood nature of IS' Al-Hayat English language production company videos, testimonials and documentaries. At its peak Islamic state social media reached millions through You Tube, Twitter and Facebook and it employed a sophisticated team of internet hackers [Cyber Caliphate] to attack its enemy's web sites. ${ }^{88}$ In their 2015 study of ISIS social media use J.M. Berger and Jonathan Morgan estimated that by December 2014 some 46,000 Twitter accounts devoted to promoting the group's message. $^{89}$

The organization's cohesiveness, moreover, contrasts with the Mahdist state. Though divisions are endemic to jihadist networks, the Islamic State remains notably free of organizational fissures. During Khalifa Abdullah's 13 year Mahdiyyah he faced internal rebellions including some religious revolts in Western Sudan. ${ }^{90}$ Islamic State unity also contrasts with its Al Qaeda progenitor that has fractured badly since the destruction of its Afghan pre 9-11 sanctuary. ${ }^{91}$

\section{The MAHDists DeMiSe Foreshadows the ISLAMIC STATE'S DESTRUCTION}

The Mahdiyyah's thwarted Britain's regional interests for 13 years. Its endurance is due to numerous factors. The British led, armed and advised Egyptian-Sudanese army was incapable of sustaining offensive operations into the Sudan. The Egyptian army's poor leadership, low morale and inadequate arms were exacerbated by British hesitance to decisively confront the Mahdist state. ${ }^{92}$ Despite repeated calls to avenge the hero of Khartoum General "Chinese" Gordon, Gladstone resisted these pleas. Other factors intervened. Khalifa Abdullah's suppression of internal revolts and his religious authority as the Mahdi's successor offered enough deterrent capacity to ward off invading armies. The brutality and fanaticism of his Ansar warriors intimidated potential opponents.

The parallel to US policy toward IS is compelling. Exhausted by six years of war in Iraq that resulted in over four thousand fatalities and having spent hundreds of billions, the Obama administration was eager to disengage from the country. Given Barak Obama's opposition to the 2003 Iraq war his determination to work out a long-term US security presence in Iraq was less than firm. Having failed to finalize a long term US security presence in Iraq, US forces withdrew in 2011. Such a policy was consistent with the Administration's "realist" pivot to Asia and desire to end the "war on terrorism". ${ }^{93}$

Like Gladstone, Obama was content to assist regional actors to secure US vital interests and avoid direct decisive American military intervention. With ISIS' summer 2014 military victories and the collapse of Iraqi army, the illusive quest to leave the Mideast abruptly ended. As ISIS forces advanced toward Erbil and endangered Baghdad, Obama reluctantly embarked on a campaign of targeted air strikes against ISIS positions and he redoubled training, financing and arming of Iraqi and Kurdish security forces. Content to let Baghdad lead the fight against ISIS, Obama initially refused to commit US combat forces. With the caliphate's one year anniversary, the Administration policy to "degrade" and "destroy" IS proved frustratingly illusive. Britain's early use of Egyptian forces to fight its

\footnotetext{
${ }^{87}$ Kelshall, C. "ISIL: the Ultimate Hybrid Enemy" at http://www.defenseiq.com/air-land-and-sea-defenseservices/articles/isil-the-ultimate-hybrid-enemy/. The author puts ISI forces between 90,000-200,000 which vastly exceeds the 20,000 figure cited by the CIA and US military sources.

${ }^{88}$ Saltman EM, and Charlie Winter, "Changing the Face of Modern Jihadism" Quillium Foundation November 2014 accessed at: http://www.quilliumfoundation.org/fee-publications/

${ }^{89}$ Berger, JM. and Jonathan Morgan. "The ISIS Twitter Census: Defining and describing the population of ISIS supporter on Twitter" Analysis Paper No. 20 March 2015 The Brookings Project on US Relations with the Muslim World accessed at: http://www.brookings.edu/-/media/research/files/paper/2015/03/ISIS-twitter-censusberger-morgan/ISIS-twitter-census-berger-morgan.pdf

${ }^{90}$ Kapteijans, L. "Mahdist Faith and the Legitimation of Popular Revolt in Western Sudan" Africa 55:4 390-399

${ }^{91}$ Celso, A. Al Qaeda Post 9-11 Devolution: the Failed Jihadist War against the Near and Far Enemy (Bloomsbury Press: New York, 2014)

${ }^{92}$ Moore-Harell, A. "The Turco-Egyptian Army in the Sudan on the Eve of the Madiyya" International Journal of Middle Eastern Studies 31:1 19-31

${ }^{93}$ Duek, C. "The Strategy of Retrenchment and its Consequences" FPRI e-note April 2015 accessed at http://www.fpri.org/document/duek___retrenchment.pdf
} 
jihadist enemies was similarly ineffective. The 1895 victory of the Conservative opposition, however, changed this dynamic. Not encumbered by a hesitancy to use military force to defend British imperial interests, the Conservatives were also fearful of Italian colonial designs on Abyssinia. Fearing that if it failed to act in the Sudan, the territory would fall to other European powers, Britain was determined to avenge Gordon's death at Khartoum.

Within a few years, the British formed a well-armed and trained expeditionary force in Egypt. Composed of 8,000 British forces and over10,000 Egyptian-Sudanese troops, General Horatio Kitchener's army was assisted by rail network that guaranteed his forces supplies. ${ }^{94}$ Confronted by a well-armed professional force the Mahdist state by 1898 found its days numbered. Sudan's harsh climate and the Khalifa's need to defend water supplies and markets critical for the Mahdiyyah's physical and financial survival, prevented him from drawing Kitchener's force into the hinterlands. ${ }^{95}$ Unlike previous military campaigns where expeditionary forces survived off the land, an advanced rail network kept the British-Egyptian army transported, well fed and armed.

With no dense metropolitan populations to hide his Ansar forces Khalifa Abdullah could not practice urban terrorist warfare. Faced with the lack of an asymmetric warfare option, the Ansar were forced to confront British forces openly on the battlefield. At Omdurman the Khalifa had amassed 50,000 men armed with antiquated rifles, rudimentary cannon and spears. Having the advantage of a larger force Abdullah was moved by a prophetic dream promising victory over crusader forces in an open field similar to Omdurman's plains. Rejecting a night assault, Abdullah engaged British forces that were armed with machine guns and howitzers. The resulting slaughter was imminently predicable. ${ }^{96}$ British forces could not but admire the bravery and determination of the Ansar warriors as their dead bodies amassed on the battlefield. Winston Churchill's account of the Sudanese campaign is effusive about the bravery of Abdullah's Ansar warriors. ${ }^{97}$ Close to 11,000 jihadist martyrs perished at Omdurman and within a year Abdullah's retreating army was hunted down. Khalifa. Abdullah was killed in battle the victim of yet another prophetic vision promising victory. Not bound by political correctness the British bombed the Mahdi's tomb and dug up his burial site throwing his bones into the river. British colonial authorities banned and criminalized Mahdists cults. ${ }^{98}$ At Omdurman the savagery and decisiveness of the British military response had vanquished the Mahdiyyah.

Like the British before him Obama was forced by circumstances to recommit US troops to Iraq and then later to Syria. By the end of his term over 5,000 soldiers were deployed to the region mainly in an advisory and Special Forces operations role. With a redoubled training efforts by thousands US advisors, the Iraqi army and Syrian Kurdish proxies gained the capacity to sustain offensive operations against IS' positions. ${ }^{99}$ By 2016 the tide had been turned and IS was steadily losing territory in Iraq and Syria. One year later the caliphate lost some forty-five thousand fighters and nearly all of the territory it conquered in its 2014 military victories. Its twin capitals of Mosul and Raqqa were liberated from IS' tyrannical rule at the end of last year. With the exception of Abu Bakr al-Baghdadi most of IS's leadership has been killed.

How does the Mahdiyyah's fall foreshadow IS's collapse? While differences abound the similarities are striking. Like the Mahdi's Ansar the Islamic State was prone to strategic impatience on the battlefield engaging in open battle with calamitous consequences. Michael Knight argues that IS was

\footnotetext{
${ }^{94}$ Holt, The Mahdist State in the Sudan ibid, 239-241

${ }^{95} \mathrm{Sieg}, \mathrm{HM}$, "How the Transformation of Military Power over Time to Increasing Asymmetries in Warfare: the Battle of Omdurman to the Iraq Insurgency" Armed Forces and Society 40:2 332-356

96 Ibid.

${ }^{97}$ Churchill, W.The River War: an Account of the Re-conquest

of the SudanKindle Edition 95-99

${ }^{98}$ Holt, ibid, 241

${ }^{99}$ Knights, M. and Jabbar Jaafar, "Restoring the Iraqi Army’s Pride and Fighting Spirit" July 8, 2015 The Washington Institute for Near East Policyaccessed at http://washingtoninstitute.org/policy-analysis-restoring-thiraqi-army-pride-and-fghting-spirit.pdf
} 
badly served by its "cult of the offensive". ${ }^{100}$ The caliphate's human wave assaults on the Syrian Kurdish enclave of Kobani in 2014 was met with devastating US air strikes, and the battle has its precedent in the failed Mahdist charges at Obeid and Omdurman. IS ideologues put faith in prophetic visions. The fanatical pretensions of jihadist leaders like Abu Bakr al-Baghdadi and Caliph Abdullah force their fighters into strategically disadvantageous situations. Baghdadi's call for IS to defend Mosul to the last man badly depleted his fighting force, presaging its later collapse in town like Tal Afar and Mayadln. ${ }^{101}$ Like the Mahdists and the Saudi Juhayan cult, IS militarily miscalculated to devastating effect.

By creating a state IS was vulnerable to firepower that destroyed its institutional foundations. ${ }^{102}$ IS's provincial Shura administration operated openly to dispense justice and administer services. The caliphate's governing apparatus was eviscerated by three years of mass bombing. By June 2017 the Islamic State lost $60 \%$ of its territory and $80 \%$ of its revenue. ${ }^{103}$ At the end of the 2017 US air campaign against IS's Syrian capital Raqqa the city looked very much like Dresden during the Second World War. Its vanquishing at the hands of American supported Kurdish-Arab forces effectively put an end to the Islamic State's vision of its new Medina.

The caliphate's finances were dependent upon Syrian oil production facilities that were destroyed by targeted air strikes. Revenue from oil sales by 2015 went down by some two-thirds. ${ }^{104}$ While IS remains adept at asymmetric warfare, its main 2014 advances came through hybrid warfare assaults against weak and divided opponents. Once those enemies rallied and coordinated their military actions IS' fate was sealed. The eight month long Iraqi military offensive to take Mosul from the Islamic State featured Kurdish Peshmerga, Shia militias, Sunni tribal groups and Iraqi army special forces that while suffering immense casualties killed thousands of IS fighters most of whom headed Baghdadi's call to fight to the death. Given IS targeting of these groups they had little choice but unite or face annihilation.

Like the Mahdists the Islamic State was forced to openly defend its governance project that was destroyed with massive firepower. Defeating the Islamic State as a terror-insurgent network, however, will not beas easy as Britain's vanquishing of the Madiyyah. With its clandestine guerrilla fighters, illicit finances and still significant following, IS remains a formidable opponent. The continuing ethno-sectarian antagonisms across the region and the existence of weak and failing states guarantee space for terrorist safe havens. Absent a resolution of these thorny problems the Islamic State is likely to persist.

The caliphate's destruction does not end IS as a global terror and insurgent organization. Its regional appendages in Egypt, Afghanistan, Somalia, Nigeria, Yemen, Libya and elsewhere remain. Unlike the Mahdi's followers IS will persist as an international underground movement across the Levants killed at urban terrorism and sophisticated guerrilla warfare. After the Mahdiyyah's fall British colonial authorities never experienced a serious challenge to their rule. This is not the case with the Islamic State.

Having defeated IS's progenitor Al Qaeda in Iraq (AQI) by 2010 US authorities were sufficiently confident that Iraqi security services acting alone were capable of containing the jihadist network. They were tragically wrong. Iraqi Prime Minister Haidar al- Abadi's 2017 declaration of victory over the Islamic State may be equally erroneous. What the Mahdiyyah and Islamic State's demise tells us, however, is that transnational jihadist states committed to societal transformation and international military expansion are unsustainable. Willed by religious fanaticism such states are impervious to

\footnotetext{
${ }^{100}$ Knights, M. and Alexander Mello, "Cult of the Offensive: ISIS on the Defensive" CTC Sentinel 8:4 1-5

${ }^{101}$ Hasan Hasan, "Insurgents Again: The Islamic State's Calculated Reversion to Attrition in the Syria-Iraq Border Region and Beyond" CTC Sentinel 10:11 1-8

${ }^{102}$ Flynn, MT. "Why the Iraq Offensive Will Fail." POLITICO Magazine. February 20, 2015. http://www. politico.com/magazine/story/2015/02/why-the-iraq-offensive-will-fail 115356.html\#.VZVGqmYpCAw

${ }^{103}$ Carlino, L. "The IS Economy: Will Losing Territory Cripple the Islamic State" December 9, 2017 Terrorism Monitor 15:23 accessed at: https://jamestown.org/program/economy-will-losing-territory-cripple-islamic-state/

${ }^{104}$ Levitt, M. "Countering ISIL Financing: A Realistic Assessment" February 2, 2015 accessed at http://www.washingtoninstitute.org/uploads/documents/Levittstatement/20150502v.3.pdf
} 
The Islamic State (IS) and the Sudanese "Mahdiyyah": A Comparative Analysis of Two Failed Apocalyptic Jihadist States

reason for they embark on a policy of total war against real and imaginary enemies. As Mohammad Hafez notes fratricidal jihadists repeatedly fail to learn from their past mistakes because they are blinded by religious zeal. ${ }^{105}$ Given the number of opponents they create they are doomed to fail. Yet despite such past missteps the centrality of restoring the caliphate in jihadist ideology and the theological frenzy it generates is guarantor of permanent unresolved conflict.

Citation: Dr. Anthony Celso. "The Islamic State (IS) and the Sudanese "Mahdiyyah": A Comparative Analysis of Two Failed Apocalyptic Jihadist States". International Journal of Political Science (IJPS), vol4, no.1, 2018, pp.28-42. doi:http://dx.doi.org/10.20431/2454-9452.0401004.

Copyright: (C) 2018 Authors. This is an open-access article distributed under the terms of the Creative Commons Attribution License, which permits unrestricted use, distribution, and reproduction in any medium, provided the original author and source are credited.

\footnotetext{
${ }^{105}$ Mohammad Hafez, "The Curse of Cain: Why Fratricidal Jihadis Fail to Learn from Their Mistakes" CTC Sentinel 10:10 1-7 